Ambiente \& Água - An Interdisciplinary Journal of Applied Science
ISSN 1980-993X - doi:10.4136/1980-993X
www.ambi-agua.net
E-mail: ambi.agua@gmail.com

\title{
Presence of pesticides, mercury and trihalomethanes in the water supply systems of Ibagué, Colombia: threats to human health
}

\author{
ARTICLES doi:10.4136/ambi-agua.2477
}

Received: 25 Sep. 2019; Accepted: 16 Feb. 2020

\section{Blanca Lisseth Guzmán Barragán ${ }^{*}$ (D); Manuel Alejandro Gonzalez Rivillas ${ }^{2}$ iD; Manuel Salvador Cuero Villegas ${ }^{3}$; ; Jóse David Olivar Medina ${ }^{2}$}

\author{
${ }^{\mathbf{1}}$ Facultad de Ciencias Agropecuarias. Universidad de Ciencias Aplicadas y Ambientales (U.D.C.A), Calle 222, \\ $\mathrm{N}^{\circ}$ 55-37, Postal Code: 111166, Bogotá, Cundinamarca, Colombia \\ ${ }^{2}$ Ibagué Saludable. Alcaldía de Ibagué. Secretaría de Salud Municipal de Ibagué, Calle 9 N² 2-59, Ibagué, \\ Tolima, Colombia. E-mail: malejandrogonzalezr@gmail.com, olivarjose10@gmail.com \\ ${ }^{3}$ Ciencias Biologicas. Universidad del Tolima (UT), Calle 42, S/N, Postal Code: 730006299, Ibagué, Tolima, \\ Colombia. E-mail: manuelcuerovillegas@hotmail.com \\ *Corresponding author. E-mail: blancalissethguz@hotmail.com
}

\begin{abstract}
Chemical contamination of the water supply system caused by anthropic activities can cause adverse health effects. This study determined the presence of toxic metals, organic substances, pesticides and trihalomethanes in the water supply systems of the urban area of Ibague City. The economic and sanitary activities located in the 25 surface streams of the 32 water supply systems of the municipality were characterized. A total of 25 water samples were taken from the surface streams, and 35 samples in the water network of each drinking water service provider for the identification of pesticides (carbamates, organochlorines, organophosphorus), mercury, arsenic, cyanide, lead, cadmium, antimony, cobalt, selenium, silver, nickel and hydrocarbons. The presence of trihalomethanes was sampled after the treatment process given. A total of 775 economic and sanitary activities were detected in the surface streams of the water supply systems, highlighting the human settlements, agricultural and tourist activities impact on the water sources. Organochlorine pesticides (0.009-0.109 $\mathrm{mg} / \mathrm{L})$, mercury (0.001-0.004 $\mathrm{mg} / \mathrm{L})$ were identified in the water supply system in concentrations higher than those permitted by local regulation. Concentrations of trihalomethanes $(0.064-1.260 \mathrm{mg} / \mathrm{L})$ were detected in $68.7 \%$ of the water supply systems with treatment. The presence of chemical contaminants occurs mainly in communities with water supply systems of low complexity with high anthropic affectation. It is necessary to strengthen the assessment of hazards and risk by health surveillance, as well as intersectoral intervention for the protection of water sources and the improvement of water treatment technologies.
\end{abstract}

Keywords: environmental health, mercury, pesticides, trihalomethanes, water contamination.

\section{Presença de pesticidas, mercúrio e trialometanos na água para consumo humano em Ibagué, Colômbia: ameaças à saúde humana}

\section{RESUMO}

A contaminação química do abastecimento da água causada por atividades antrópicas pode causar efeitos adversos à saúde. O presente estudo propõe determinar a presença de metais 
Blanca Lisseth Guzmán Barragán et al.

tóxicos, substâncias orgânicas, pesticidas e trihalometanos dos sistemas de abastecimento da cidade de Ibague, Colômbia. Foram caracterizadas as atividades econômicas e sanitárias presentes em 25 fontes de água superficial de 32 sistemas de abastecimento de água da área urbana do município. Se coletaram 25 amostras de água das fontes superficiais de água e 35 amostras do sistema de abastecimento de água para identificação de pesticidas (carbamatos, organoclorados, organofosforados), mercúrio, arsênico, cianeto, chumbo, cádmio, antimônio, cobalto, selênio. prata, níquel e hidrocarbonetos. A presença de trihalometanos foi avaliada no pós-tratamento. No total, 775 atividades econômicas e sanitárias foram detectadas nas fontes de água superficial do sistema de abastecimento de água, destacando o impacto dos assentamentos humanos, das atividades agrícolas e turísticas nas fontes de água. Pesticidas organoclorados $(0,009-0,109 \mathrm{mg} / \mathrm{L})$, mercúrio $(0,001-0,004 \mathrm{mg} / \mathrm{L})$ foram identificados no sistema de abastecimento de água em concentrações superiores às permitidas pelos regulamentos. Concentrações de trihalometanos $(0,064-1,260 \mathrm{mg} / \mathrm{L})$ foram detectadas em $68,7 \%$ do sistema de abastecimento de água com tratamento. A presença de contaminantes químicos ocorre principalmente no abastecimento de água comunitaria de baixa complexidade com alta afetação antrópica. É necessário fortalecer a avaliação de perigos e riscos pela vigilância sanitária, bem como a intervenção intersetorial para a proteção de fontes de água e o aprimoramento das tecnologias de tratamento de água.

Palavras-chave: contaminação da água, mercúrio, pesticidas, saúde ambiental, trihalometanos.

\section{INTRODUCTION}

Water quality is an essential component of public health. Chemical contamination of water sources is increasing; $30 \%$ of sweet water is used by industry and municipalities, generating large areas of highly contaminated wastewater. Anthropogenic activities, such as industry, agriculture, and discharge of large amounts of organic and inorganic toxic fuels, increase the health risks associated with these substances (Schwarzenbach et al., 2010, Fawell and Nieuwenhuijsen, 2003). Industrial pollutants intensify the contamination of water systems because treatments that control infectious agents are not effective in removing many toxic chemicals from drinking water (Landrigan, 2018).

In Colombia, the quality of water supply is regulated by Decree No. 1575/2007 and Resolution No. 2115/2007 (Colombia, 2007). In routine surveillance, some chemical substances are monitored, among them: zinc, calcium, phosphates, manganese, molybdenum, sulfates, chlorides, iron, aluminum, calcium, fluorides, nitrites, nitrates and magnesium. However, toxic chemicals, such as pesticides, mercury, arsenic, cyanide, lead, cadmium, antimony, cobalt, selenium and silver, are not routinely monitored by Colombian sanitary surveillance. In these cases, the toxic chemical substances are subject to surveillance if anthropic activities associated with the release of these substances are identified in water sources of the water supply system and their presence confirmed in the water supply according to Resolution No. 4716/ 2010 (Colombia, 2010).

The increase in local agriculture, industry, mining, and increasing urbanization in Colombia implies an increase in potentially toxic substances in the water. An evaluation of the progress towards the goals for drinking water access of the Millennium Development Goals (MDGs) for Colombia shows a level of partial compliance with the established goals. By 1990, $88 \%$ of the total population had safe water sources, distributed in $97 \%$ of the urban population and $69 \%$ of the population in the rural areas, for which a goal of $99.2 \%$ and $78.1 \%$ respectively was established. By 2014, 91\% of the population had access to safe water sources, $97 \%$ in urban areas and rising to $74 \%$ in rural areas, evidencing enormous inequities in the provision of the public service of safe water between these sectors, as well as critical territorial gaps that deserve 
priority attention (UN, 2015).

It is essential to understand that safe sources of water are defined as connections to the water supply, pipe, well, pump, bottled water, tank car, and public battery. In this definition, there is no emphasis on the evaluation of potability standards. Therefore, many safe water sources must be monitored for quality to determine their true impact on health.

The monitoring of water quality carried out in 1,067 municipalities $(96.8 \%)$ of Colombia in 2014 pointed out the problems of water quality, considering that only 195 (18.3\%) met the standards established by the Colombian regulations presenting an acceptable IRCA (Water Quality Risk Index) of 502 (47\%) within the partial compliance range, and 370 (34.7\%) did not comply with the established standards (Guzman et al., 2015). The present study evaluated the presence of toxic metals, organic substances, pesticides and trihalomethanes in the water supply system of the urban area of the municipality of Ibagué, Colombia, considering the sanitary surveillance guidelines established in Resolution No. 4716/ 2010 in order to discuss its contributions and challenges.

\section{METHODOLOGY}

\subsection{Study area}

The study was conducted in the city of Ibague located in the center-west of Colombia, on the central mountain range coordinates $4^{\circ} 26^{\prime} 16^{\prime \prime} \mathrm{N}, 75^{\circ} 12^{\prime} 02^{\prime \prime} \mathrm{W}$ at an altitude of 1,285 meters above sea level, with average annual total rainfall of $1,691 \mathrm{~mm}$, and temperatures between $20^{\circ}$ and $28^{\circ} \mathrm{C}$ (IDEAM, 2017). The city has a territorial extension of $1,439 \mathrm{~km}^{2}$, administratively divided in 13 communes in the urban area and 17 rural settlements, with a total of 558,805 inhabitants according to projections of the National Administrative Department of Statistics DANE 2018 (Colombia, 2011). It has a total of 32 water supply systems in the urban area. The municipal water supply and sewerage service company serves $80 \%$ of the population, and 31 low complexity community-type water supplies, which serve $20 \%$ of the population in those sites of difficult access; only 16 water supplies have treatment plants built and operating. The water supply consists of 25 surface water sources that belong to the basins of Rio Totare, Rio Coello and Rio Opia.

\subsection{Characterization of economic and sanitary activities in water sources}

The activities that affect the quality of the surface water source of the water supply system were identified, for which a survey was carried out with the environmental authorities and the water supply service companies. Subsequently, a characterization of the economic and sanitary activities present upstream of the intake was carried out through field visits by inspectors. To this purpose, a technical sheet was prepared which allowed the gathering of the economic and sanitary information of the water source: type of activities, coordinates, possibly associated chemical inputs, and occasional discharges. The characterization of the activities was carried out between September and December of 2017. During this period three trips were made through the water basin: one through the main channel of the basin and two through routes by the water dividing lines that delimit each basin (left and right limits of the basin), trying to cover the greatest of area. Subsequently, technical sheets were completed, and the activities were georeferenced using Trimble GPS equipment SPS780 with a TSC2.SC.900 antenna. The information collected was systematized, and the coordinates were graphically mapped within the geodetic network of the Instituto Geográfico Agustín Codazzi-GAC using ArcGis software with its Arsmap 10.5 application.

\subsection{Sampling}

A total of 60 water samples were taken: 25 samples, one in each surface water source of the pump intake, and 35 starting points of the distribution networks of the water supply system. 
Four samples of the municipal water supply were taken due to the population served, and one sample for the communal water supply. The sampling was carried out in December 2017, following the guidelines for taking and presenting samples (APHA et al., 2005; Instituto Nacional de Salud, 2011), considering the specifications of each characteristic (see Table 1). The temperature and $\mathrm{pH}$ were measured in the samples taken. The reading of the free residual chlorine was included in the treated samples. The samples were then stored in refrigerators to keep them at temperatures from $2^{\circ} \mathrm{C}$ to $4^{\circ} \mathrm{C}$, to be transported to the reference laboratory in Bogotá DC, considering the chain of custody, biosecurity measures and preservation conditions for transportation in order to guarantee the integrity of the sample.

Table 1. Preservation of the samples.

\begin{tabular}{|c|c|}
\hline COMPOUND & PRESERVATION \\
\hline $\begin{array}{l}\text { Arsenic, cadmium, mercury, nickel, } \\
\text { silver, lead, selenium, antimony, cobalt, } \\
\text { carbamate }\end{array}$ & $\begin{array}{l}\mathrm{HNO}_{3} \text { was added until } \mathrm{pH}<2 \text { was obtained and cooled to } \\
\leq 6^{\circ} \mathrm{C}\end{array}$ \\
\hline Hydrocarbons & $\begin{array}{l}\text { Addition of } \mathrm{HCl} \text { or } \mathrm{H}_{2} \mathrm{SO}_{4} \text { until } \mathrm{pH} \leq 2 \text {, Refrigerate at } \leq \\
6^{\circ} \mathrm{C}\end{array}$ \\
\hline Free cyanide & $\mathrm{NaOH}$ until $\mathrm{pH} \leq 12$. Refrigerate at $\leq 6^{\circ} \mathrm{C}$ \\
\hline Organochlorine pesticides & $\begin{array}{l}\text { Refrigerate at } 4^{\circ} \mathrm{C} \text { to } 6^{\circ} \mathrm{C} \text {. If additional chlorine is present } \\
\text { (sodium thiosulfate } 0,92 \mathrm{~mL} \text { at } 10 \% \text { ), adjust pH from } 5 \text { to } \\
8 \text { with either } \mathrm{NaOH} \text { or } \mathrm{H}_{2} \mathrm{SO}_{4}\end{array}$ \\
\hline Organophosphorus pesticides & $\begin{array}{l}\text { Refrigerate at } 4^{\circ} \mathrm{C} \text { to } 6^{\circ} \mathrm{C} \text {. Adjust } \mathrm{pH} \text { from } 5 \text { to } 8 \text { with either } \\
\mathrm{NaOH} \text { or } \mathrm{H}_{2} \mathrm{SO}_{4}\end{array}$ \\
\hline Trihalomethanes & Cool to $\leq 2^{\circ} \mathrm{C}$ \\
\hline
\end{tabular}

\subsection{Laboratory analysis}

The samples were processed in the Laboratory of Analysis of Water and Soils of Colombia ANASCOL S.A.S., a laboratory accredited by the Institute of Hydrology, Meteorology and Environmental Studies - IDEAM and the Interlaboratory Program of Quality Control of Drinking Waters -PICCAP. The parameters were analyzed in both raw and treated water; trihalomethanes were only analyzed in treated water (see Table 2). The methodologies for analyzing the selected characteristics were carried out according to the guidelines of the "Standard Methods for the Examination of Water and Wastewater," Edition 21 (21). The samples were processed in December 2017 and January 2018. The minimum values detectable by the techniques used are presented in Table 2 ; the results obtained were evaluated considering the minimum values acceptable by the resolution $N^{\circ} 2115 / 2007$ of Colombia. The analysis of the presence of contaminants was carried out for the treated water supply systems and is not treated separately, considering the samples in the surface water source and in the supply network. 
Table 2. Analytical characteristics and methodology for the analysis of the chemical water quality of the urban water supply of Ibagué, Colombia, 2017.

\begin{tabular}{|c|c|c|c|}
\hline VARIABLE & METHOD & $\begin{array}{l}\text { MDV } \\
* \\
(\mathrm{mg} / \mathrm{L})\end{array}$ & $\begin{array}{c}\text { MVA } \\
* * \\
(\mathbf{m g} / \mathrm{L})\end{array}$ \\
\hline \multicolumn{4}{|c|}{ TOXIC METAL } \\
\hline Arsenic & $\begin{array}{l}\text { Atomic Absorption Spectrophotometry - Manual hydride } \\
\text { generation. SM3114B }\end{array}$ & 0.01 & 0.01 \\
\hline Cadmium & $\begin{array}{l}\text { Digestion Nitric Acid-SM } 3030 \text { E-Atomic Absorption } \\
\text { Spectrophotometry direct flame Air-Acetylene. SM 3111B }\end{array}$ & 0.001 & 0.003 \\
\hline Mercury & Atomic Absorption Spectrophotometry - Cold Vapor. SM3112B & 0.001 & 0.001 \\
\hline Nickel & $\begin{array}{l}\text { Digestion Nitric Acid-SM } 3030 \text { E-Atomic Absorption } \\
\text { Spectrophotometry direct flame Air-Acetylene. SM 3111B }\end{array}$ & 0.005 & 0.02 \\
\hline Silver & $\begin{array}{l}\text { Nitric Acid Digestion-SM } 3030 \text { E- Atomic Absorption } \\
\text { Spectrophotometry direct flame Air-Acetylene. SM 3111B }\end{array}$ & 0.02 & NR \\
\hline Lead & $\begin{array}{l}\text { Nitric Acid Digestion-SM } 3030 \text { E- Atomic Absorption } \\
\text { Spectrophotometry direct flame Air-Acetylene. SM 3111B }\end{array}$ & 0.005 & 0.01 \\
\hline Selenium & $\begin{array}{l}\text { Atomic Absorption Spectrophotometry - Manual hydride } \\
\text { generation. SM3114B }\end{array}$ & 0.0005 & 0.01 \\
\hline Antimony & $\begin{array}{l}\text { Digestion Nitric Acid-SM } 3030 \text { E-Atomic Absorption } \\
\text { Spectrophotometry direct flame Air-Acetylene. SM 3111B }\end{array}$ & 0.3 & 0.02 \\
\hline Cobalt & $\begin{array}{l}\text { SM } 3030 \text { E SM } 3113 \text { B Digestion - AA - Graphite Oven } \\
\text { (Electrothermal) }\end{array}$ & 0.001 & NR \\
\hline \multicolumn{4}{|c|}{ ORGANIC SUBSTANCES } \\
\hline Dissociable cyanide & Distillation - Volumetric. SM 4500CN - A. B. C. D. I & 0.4 & 0.05 \\
\hline Hydrocarbons & $\begin{array}{l}\text { Partition - Infrared / Determination Hydrocarbons. NTC 3362: } \\
\text { 2011-11-30 Numeral 4. Method C / Numeral 7. Modified Method F. }\end{array}$ & 1 & 0.01 \\
\hline \multicolumn{4}{|c|}{ PESTICIDES } \\
\hline Carbamates & $\begin{array}{l}\text { China National Standard Method GB / T 5009.104-2003 Liquid- } \\
\text { liquid extraction, CG / NPD }\end{array}$ & 0.01 & 0.0001 \\
\hline $\begin{array}{l}\text { Organochlorine } \\
\text { pesticides }\end{array}$ & $\begin{array}{l}\text { Liquid-Liquid Extraction. EPA } 3510 \text { C. Revision 3. December } \\
\text { 1996- Gas Chromatography with Electron Capture Detector (GC } \\
\text { / ECD). EPA 8081B. Revision 2. February } 2007\end{array}$ & 0.005 & 0.0001 \\
\hline $\begin{array}{l}\text { Organophosphorus } \\
\text { pesticides }\end{array}$ & $\begin{array}{l}\text { Liquid Liquid Extraction US-EPA 3510C Revision 3. December } \\
\text { 1996-Gas chromatography with Nitrogen-Phosphorus detector } \\
\text { (GC / NPD). US-EPA 8141B Revision 2. February } 2007 .\end{array}$ & 0.0025 & 0.0001 \\
\hline \multicolumn{4}{|c|}{ DISINFECTION SUB-PRODUCTS } \\
\hline Trihalomethanes & $\begin{array}{l}\text { SM 6232B Gas chromatography with electron capture detector } \\
\text { (GC / EDC). US-EPA } 8081 \text { B. Revision } 2 \text {. February } 2007 .\end{array}$ & 0.004 & 0.2 \\
\hline
\end{tabular}

*MDV: Minimum Detectable Value

**MVA: Acceptable Maximum Value according to Resolution $N^{\circ}$ 2115/2007 of Colombia.

\section{RESULTS AND DISCUSSION}

The laboratory results identified the presence of cadmium, mercury, and nickel in water sources and the supply network of some water supply at the established detectable concentrations. No arsenic, barium, molybdenum, silver, lead, selenium, molybdenum, cobalt, hexavalent chromium, surfactants, dissociable cyanide, hydrocarbons, carbamates and 
Blanca Lisseth Guzmán Barragán et al.

organophosphorus pesticides were detected. The reference values for cadmium, nickel and antimony were below the VMA levels established by Colombia (see Table 3).

Table 3. Results of the chemical analyses in water sources and supply network of the water supply system of the urban area of Ibagué, 2017.

\begin{tabular}{|c|c|c|c|c|c|c|c|c|}
\hline \multirow[t]{2}{*}{ Characteristic } & \multirow[t]{2}{*}{$\mathrm{UNI}^{1}$} & \multirow[t]{2}{*}{$\begin{array}{l}\text { MVA } \\
\text { COL }^{2}\end{array}$} & \multicolumn{2}{|c|}{$\begin{array}{c}\text { Results } \\
\text { (Min - Max) }\end{array}$} & \multicolumn{2}{|c|}{$\begin{array}{l}\text { Water supply system } \\
\text { with presence of the } \\
\text { Characteristic }\end{array}$} & \multicolumn{2}{|c|}{$\begin{array}{c}\text { Water supply } \\
\text { system above } \\
\text { MVA COL }\end{array}$} \\
\hline & & & $\mathbf{W S}^{3}$ & $\mathrm{SN}^{4}$ & WS & SN & WS & $\mathbf{S N}$ \\
\hline Cadmium & $\mathrm{mg} / \mathrm{L}$ & 0.003 & 0.00150 .0016 & $0.001-0.001$ & 3 & 10 & 0 & 0 \\
\hline Mercury & $\mathrm{mg} / \mathrm{L}$ & 0.001 & $0.001-0.003$ & $0.001-0.004$ & 9 & 11 & 9 & 11 \\
\hline Nickel & $\mathrm{mg} / \mathrm{L}$ & 0.02 & $0.005-0.007$ & $0.005-0.007$ & 11 & 11 & 0 & 0 \\
\hline Antimony & $\mathrm{mg} / \mathrm{L}$ & 0.02 & 0.005 & 0.03 & 1 & 0 & 0 & 0 \\
\hline $\begin{array}{c}\text { Total } \\
\text { Organochlorines }\end{array}$ & $\mathrm{mg} / \mathrm{L}$ & 0.001 & $0.018-0.056$ & 0.009-0.109 & 22 & 13 & 22 & 13 \\
\hline Alpha-BHC & $\mathrm{mg} / \mathrm{L}$ & 0.0001 & 0.01 & $0.025-0.101$ & 1 & 4 & 1 & 4 \\
\hline Heptachlor & $\mathrm{mg} / \mathrm{L}$ & 0.0001 & $\mathrm{ND}^{5}$ & 0.022 & 0 & 1 & 0 & 1 \\
\hline Aldrin & $\mathrm{mg} / \mathrm{L}$ & 0.0001 & $0.014-0.040$ & $0.075-0.064$ & 16 & 9 & 16 & 9 \\
\hline Heptachlor epoxide & $\mathrm{mg} / \mathrm{L}$ & 0.0001 & ND & $0.007-0.012$ & 0 & 2 & 0 & 2 \\
\hline Endosulfan sulfate & $\mathrm{mg} / \mathrm{L}$ & 0.0001 & $0.005-0.020$ & $0.005-0.008$ & 15 & 2 & 15 & 2 \\
\hline $\begin{array}{c}\text { Total } \\
\text { Trihalomethanes }\end{array}$ & $\mathrm{mg} / \mathrm{L}$ & 0.2 & $\mathrm{NA}^{6}$ & $0.064-1.260$ & NA & 15 & NA & 11 \\
\hline Chloroform & $\mathrm{mg} / \mathrm{L}$ & 0.2 & NA & $0.003-0.068$ & NA & 14 & NA & 0 \\
\hline $\begin{array}{l}\text { Bromodichloro } \\
\text { Methane }\end{array}$ & $\mathrm{mg} / \mathrm{L}$ & 0.2 & NA & $0,003-0,028$ & NA & 10 & NA & 0 \\
\hline $\begin{array}{l}\text { Dibromochlor } \\
\text { Methane }\end{array}$ & $\mathrm{mg} / \mathrm{L}$ & 0.2 & NA & $0,058-0.074$ & NA & 15 & NA & 10 \\
\hline
\end{tabular}

${ }^{1}$ UNI: Units ${ }^{2}$ MVA COL: Acceptable Maximum Value Colombia, ${ }^{3}$ WS: Water source, ${ }^{4}$ Supply network:, ${ }^{5}$ NR: No Report, ${ }^{6}$ NA: Does not apply.

The analysis showed the presence of mercury mainly in community-type water supplies. Mercury is found in the environment in its inorganic and organic forms. Its inorganic form is present in surface and underground waters; mercury is transformed to methylmercury that enters the human body through ingestion (Díaz-Arriaga, 2014). It mainly affects the nervous and immune system, the digestive system, skin and lungs, kidneys and eyes. Children are vulnerable to mercury poisoning, which can lead to deterioration of the developing central nervous system, as well as lung and nephrotic damage (Bose-O'Reilly et al., 2010; Counter and Buchanan, 2004).

The presence of mercury is a critical problem in public and environmental health in Colombia, due to the high exploitation of gold. More than 17 departments and 80 municipalities in the country are affected by gold mining (Díaz-Arriaga, 2014). Mercury has been identified in water sources in several regions of the country, such as the Ciénaga de Ayapel and the waters of the Cai River in the department of Chocó, as well as in the Ciénaga de Grande Achi in the department of Bolivar (Díaz-Arriaga, 2014; Marrugo-Negrete, 2015). Likewise, in the region of La Mojana, the presence of mercury in biological samples of mining workers was evidenced, establishing a statistical correlation with water sources as a source of contamination (Díaz et al., 2018).

The analysis of pesticides evidenced the presence of organochlorines in the water source of 22 water supplies (68.7\%) and the supply network of 13 water supplies $(40.6 \%)$. The organochlorines identified were Alpha-BHC, heptachlor, aldrin, heptachlor epoxide and endosulfan sulfate, but carbamates and organophosphates were not identified. The values detected in both water sources and in the supply network were above the reference VMA. Organophosphates, organochlorines, carbamates and pyrethroids are among the most 
commonly used pesticides. Organochlorine compounds can resist biodegradation, accumulate in the environment and become persistent organic pollutants that have been detected in animal and human tissues. It can have adverse effects on the endocrine system affecting the production of hormones, such as thyroid and sex hormones; in the nervous system it can cause neuronal effects and dysfunction of neurotransmitters and affect liver function besides being potentially mutagenic and carcinogenic (Hendry-Hofer et al., 2019; Nicolopoulou-Stamati, et al., 2016; Zaragoza-Bastida et al., 2016).

Pesticides have been widely identified in water sources in Colombia. At the Ciénaga de Grande de Lorica in the department of Córdoba, $\alpha-\mathrm{BCH}, \beta-\mathrm{BCH}$ and $\gamma-\mathrm{BCH}$, aldrin and heptachlor epoxide organochlorines were identified which exceeded the individual concentration of pesticides allowed by the national regulations (Lans et al.,2008). An analysis of exposure to pesticides of the inhabitants of the riverside of the Bogotá River evidenced the presence of organochlorine and organophosphorus pesticides in the river water and fish, and ethylenethiourea in human biological samples (0: in biological samples of human origin) (Monsalve et al., 2012).

With respect to water supply consumption, a study was carried out in Soacha (department of Cundinamarca) which analyzed the presence of mercury and organophosphorus and carbamate pesticide residues, identifying values below the Acceptable Maximum Values (VMA) (Silva et al., 2015). In Cali, an analysis of mercury, diuron and 2,4 diclofenac acetic acid in the city's water supply concluded that these substances were absent (Echeverry et al.,2015). The water supply systems mentioned are highly complex; the water supplies analyzed in the present study presented highly dangerous pollutants, mainly in the community water supply system, evidencing the problems of this type of system. To fulfill the goals of the SDGs (Sustainable Development Goals), it is necessary to define public policies and investments that strengthen the community treatment systems of the water supply with sustainable alternative solutions that recognize their technical-administrative nature for reaching the goals of water safety for the country.

The presence of trihalomethanes was identified in the water supply of 15 of the 16 water supplies with treatment. Chloroform, bromodichloromethane and dibromochloromethane were analyzed in 11 water supplies $(68.7 \%)$ with detected values above the VMA. Trihalomethanes are byproducts derived from the oxidation of organic matter in chlorination; they have been associated with alterations of the liver, kidney, nervous and reproductive system, showing carcinogenic and mutagenic effects (Kim et al., 2017; Sanchez, 2008). Through the analysis of trihalomethanes, values higher than those established in the regulations were identified in $68.7 \%$ of the water supplies with treatment, including conventional and communal-type water supply. In the municipality of Pereira, the presence of trihalomethanes in 75 water samples was evaluated in the water supply of the company Aguas y Aguas de Pereira, concluding that all samples showed results within the VMA established by the regulations (Vargas et al., 2015). The rate and the degree of formation of the trihalomethanes may increase depending on the concentration of chlorine and humic acids, the temperature, the $\mathrm{pH}$ and the concentration of bromide ion (WHO, 2017). The World Health Organization (WHO) recommends implementing basic strategies to reduce the concentration of trihalomethanes, such as: (a) changing process conditions (including the elimination of precursor compounds prior to the application of the disinfectant); (b) changing the disinfectant to one less prone to produce by-products in the water source; (c) use non-chemical disinfection methods; (d) eliminate them before water distribution (WHO, 2017).

In the field visits by inspectors, 29 wastewater sources were identified that flow directly into 13 water sources of 19 water supplies, $96.5 \%$ of which were derived from human settlements and 3.5\% from agricultural activities. In the characterization of the economic and sanitary activities upstream of the intake, a total of 775 activities were identified on the margin 
of the streams of the water supply. The source with the highest number of activities was the River Combeima with $19.4 \%$ (source of a water supply), followed by La Volcana Stream with $9.82 \%$ (source of one water supply), El Tejar Stream with $8.07 \%$ (source of one water supply) and La Granate Stream with 5.14\% (source of three water supply ).

The economic and sanitary activities identified are due to human settlements $(53.1 \%)$, agricultural activities (42.5\%), sand and clay extraction (1.9\%), tourism (1.7\%) and construction $(0,8 \%)$. The most significant activity was human settlements associated with the increase in population and urbanization in the peripheries, where the sources of the water supply are located. A highly diversified agricultural and livestock exploitation was observed: coffee, plantain, cocoa, kidney bean, banana, lulo (Quito orange), blackberry, corn, beans, avocado, vegetables, cassava and orange, poultry, pig, livestock, pisciculture and horse stalls, many of which are on the margin of the ravine without any delimitation. Likewise, the study identified 63 forested areas and 17 disaster zones.

There was no direct relationship between the number of economic and sanitary activities present at the water source with the presence of contaminants in the drinking water. In systems with conventional treatments, the contaminants were not identified, while in community systems that were supplied by surface sources with high percentage supply systems with contaminants and others without water contaminants were identified. It is crucial to prioritize the protection of water sources, especially in those cases not having efficient treatment. The WHO, through the Water Safety Plan, recommends monitoring the sources continuously by service providers. Knowing the nature of the quality of the raw water, the dynamics of the water sources, the changes related to weather phenomena or other circumstances, including runoff or recharge processes, as well as verifying and correcting land use in the catchment basin, is required in order to carry out risk management at the water sources of the water supply.

In the monitoring of the water quality in terms of the chemical pollutants studied, there are significant limitations that must be overcome in order to be able to evaluate more rigorously the risks to health derived from those chemicals that are considered in the regulations. These include the analysis of health effects associated with such chemicals, considering the frequency of exposure and the concentrations at which the population will be exposed. The likelihood of health effects depends on toxicity and concentration, but also depends on the period of exposure, since for most chemicals, health impacts are associated with long-term exposure (UN, 1999).

The regulations establish that the definition of the characteristics that must be analyzed in the water source and the water supply is determined from the field visits by inspectors; 29 wastewater sources were identified that flow directly into 13 water sources of 19 water supplies of the economic and sanitary activities upstream of the intake. It is essential to mention that there are difficulties in performing exhaustive field visits by inspectors, considering the geographical adversity and the runoff potential of the leachate, adding a significant margin of error. Subsequently, the sampling established for the identification of these pollutants in the water source and the distribution network is annual or semi-annual, depending on the population served, sampling that is not quite representative, knowing the dynamics of the basins of the water sources. The definition of the characteristics monitored in the supply network is taken from the sampling, and the results of the first sample carried out in the water source which, as mentioned, is poorly representative, being that the definition of contaminants in the network will be subjective. In this study, we detected contaminants present in the water supply and not in the water source, as well as mining contaminants without their prior identification in the field visits by inspectors.

Another important aspect is the analytical availability in the territories; it is crucial to consider that the analysis of these parameters is recent in the regulations and the methodologies present high costs. Many of the territories do not have an adequate laboratory setup for testing 
these substances and few laboratories in the national public health network have implemented these methodologies. On the other hand, the methodologies available in some cases are not able to identify low concentrations of the substance analyzed. Therefore, laboratories require strengthening of their infrastructure and laboratory techniques, as well as their measurement and calibration capabilities.

Finally, the VMA for pesticides in the Colombian regulations are not specific for each of the chemical groups, which makes its analysis cumbersome. A general value is established for all pesticides, without considering that each one in the groups presents a particular mechanism of action and established lethal dose. It is essential, then, to develop regulations relating to the analysis of pesticides in water in Colombia. The regulations in the legal frameworks of Brazil, Chile, Uruguay and Venezuela follow the guidelines of WHO, where there are specifications for each chemical group of pesticides (Pinto et al., 2012).

\section{CONCLUSIONS}

This study identified the presence of contaminants such as mercury, pesticides and trihalomethanes in water of urban supply systems, showing the weaknesses of the treatment system in eliminating these high risk chemical substances. It is observed that some supply systems with "safe sources" have chemical contamination, which makes it essential to determine the real risk to the populations served by these systems, considering the presence of water contaminants.

The results show the lack of protection of the hydraulic sources of urban aqueducts, associated with the presence of economic and sanitary activities and discharges from settlements, agriculture, mining, tourism and construction that increase the pollution load of the sources. It is therefore necessary to strengthen the monitoring of water sources and to promote the timely management of hazards at the sources.

It is also important to strengthen the analysis of chemical substances and the evaluation of hazards and risk by the health authorities. Water quality monitoring should opt for new, more representative and accurate tools to assess the quality of drinking water and its impacts on health.

\section{ACKNOWLEDGEMENTS}

This study was funded by the Mayor's Office of Ibagué, in support of the development of research that strengthens Public Health Actions.

\section{REFERENCES}

\section{APHA; AWWA; WEF. Standard Methods for the Examination of Water and Wastewater.} 21. ed. Washington, 2005. p. 541.

BOSE-O'REILLY, S.; MCCARTY, K. M.; STECKLING, N.; LETTMEIER, B. Mercury exposure and children's health. Current Problems in Pediatric and Adolescent Health Care, v. 40, p. 186-215, 2010. 10.1016/j.cppeds.2010.07.002

COLOMBIA. Departamento Administrativo Nacional de Estadísticas. Estimación estadísticas vitales en los niveles de departamentos y municipio. Bogotá, 2011.

COLOMBIA. Ministerio de la Protección Social. Ministerio de Ambiente, Vivienda y Desarrollo Territorial. Resolución 2115 de 22 junio de 2007, por medio de la cual se señalan características, instrumentos básicos y frecuencias del sistema de control y vigilancia para la calidad del agua para consumo humano. Diario Oficial, Bogotá, n. 46679, 4 julio 2007. 
COLOMBIA. Ministerio de la Protección Social. Ministerio de Ambiente, Vivienda y Desarrollo Territorial. Resolución 4716 de 21 diciembre de 2010, por medio de la cual se reglamenta el parágrafo del artículo 15 del Decreto 1575 de 2007. Diario Oficial, Bogotá, n. 47930, 21 diciembre 2010.

COUNTER, S. A.; BUCHANAN, L. H. Mercury exposure in children: a review. Toxicology and Applied Pharmacology, v. 98, p. 209-230, 2004. 10.1016/j.taap.2003.11.032

DÍAZ-ARRIAGA, F.A. Mercurio en la minería del oro: impacto en las fuentes hídricas destinadas para consumo humano. Revista de Salud Pública, v. 16, p. 947-957, 2014. https://doi.org/10.15446/rsap.v16n6.45406

DÍAZ, S.; MUÑOZ-GUERRERO, M.; PALMA-PARRA, M.; BECERRA-ARIAS, C; FERNÁNDEZ-NIÑO, J. Exposure to Mercury in Workers and the Population Surrounding Gold Mining Areas in the Mojana Region, Colombia. International Journal of Environmental Research and Public Health, v. 15, p. 1-15, 2018. https://dx.doi.org/10.3390/ijerph15112337

ECHEVERRY, G.; ZAPATA, A.M.; PAÉZ, M.I.; MÉNDEZ, F.; PEÑA, M. Valoración del riesgo en salud en un grupo de población de Cali, Colombia, por exposición a plomo, cadmio, mercurio, ácido 2, 4-diclorofenoxiacético y diuron, asociada al consumo de agua potable y alimentos. Biomédica, v. 35, p. 110-19, 2015. https://doi.org/10.7705/biomedica.v35i0.2464

FAWELL, J.; NIEUWENHUIJSEN, M. J. Contaminants in drinking water Environmental pollution and health. British Medical Bulletin, v. 68, p. 199-208, 2003. https://doi.org/10.1093/bmb/ldg027

GUZMÁN, B. L.; NAVA, G.; BEVILACQUA, P. La calidad del agua para consumo humano y su asociación con la morbimortalidad en Colombia, 2008-2012. Biomédica, v. 35, p. 177-90, 2015. http://dx.doi.org/10.7705/biomedica.v35i0.2511

HENDRY-HOFER, T. B.; NG, P. C.; WITEOF, A. E.; MAHON, S. B.; BRENNER, M.; BOSS, G. R. et al. A Review on Ingested Cyanide: Risks, Clinical Presentation, Diagnostics, and Treatment Challenges. Journal of Medical Toxicology, v. 15, p. 128-133, 2019. https://dx.doi.org/10.1007/s13181-018-0688-y

INSTITUTO DE HIDROLOGIA METEOROLOGIA Y ESTUDIOS AMBIENTALES. Características climatológicas de ciudades principales y municipios. Bogotá, 2017. p. 48.

INSTITUTO NACIONAL DE SALUD. Manual de instrucciones para la toma, preservación y transporte de muestras de agua de consumo humano para análisis de laboratorio. Bogotá, 2011. p. 95.

KIM, K. H.; KABIR, E.; JAHAN, S. A. Exposure to pesticides and the associated human health effects. Science of the Total Environment, v. 575, p. 525-535, 2017. https://dx.doi.org/10.1016/j.scitotenv.2016.09.009

LANDRIGAN, P. J.; FULLER, R.; ACOSTA, N. J.; ADEYI, O.; ARNOLD, R.; BALDÉ, A. B.; et al. The Lancet Commission on pollution and health. The Lancet, v. 391, p. 462$512,2018$.

LANS, E.; NEGRETE, J. L. M.; DÍAZ, B. Estudio de la contaminación por pesticidas organoclorados en aguas de la Ciénaga Grande del Valle Bajo del río Sinú. Temas Agrarios, v. 13, p. 49-56, 2008. https://doi.org/10.21897/rta.v13i1.664 
MARRUGO-NEGRETE, J.; PINEDO-HERNÁNDEZ, J.; DÍEZ, S. Geochemistry of mercury in tropical swamps impacted by gold mining. Chemosphere, v. 134, p. 44-51, 2015. https://dx.doi.org/10.1016/j.chemosphere.2015.03.012

MONSALVE, A. S.; CRIOLLO, S. M. D.; URIBE, M. E. V.; MANTILLA, J. F. G.; FORERO, A.R. Exposición a plaguicidas en los habitantes de la ribera del río Bogotá (Suesca) y en el pez Capitán. Revista Ciencia de la Salud, v. 10, p. 29-41, 2012.

NICOLOPOULOU-STAMATI, P.; MAIPAS, S.; KOTAMPASI, C.; STAMATIS, P.; HENS, L. Chemical Pesticides and Human Health: The Urgent Need for a New Concept in Agricult. Frontiers in Public Health, v. 4 p. 148, 2016. 10.3389/fpubh.2016.00148

PINTO, V. G.; HELLER, L.; BASTOS, R. K. X. Drinking water standards in South American countries: convergences and divergences. Journal Water and Health, v. 10, p. 295-310, 2012. https://doi.org/10.2166/wh.2012.087

SÁNCHEZ, Z. A. Efectos de los trihalometanos sobre la salud. Higiene Sanidad Ambiental, v. 8, p. 280-290, 2008.

SCHWARZENBACH, R. P.; EGLI, T.; HOFSTETTER, T. B.; VON GUTEN, U.; WEHRLI, B. Global water pollution and human health. Annual Review of Environment and Resources, v. 35, p. 109-36, 2010. https://doi.org/10.1146/annurev-environ-100809125342

SILVA, E.; VILLARREAL, M. E.; CÁRDENAS, O.; CRISTANCHO, C. A.; MURILLO, C.; SALGADO, M. A. et al. Inspección preliminar de algunas características de toxicidad en el agua potable domiciliaria, Bogotá y Soacha, 2012. Biomédica, v. 35; p. 152-66, 2015. http://dx.doi.org/10.7705/biomedica.v35i0.2538

VARGAS, O. I. V.; BELTRÁN, L.; FRANCO, P; NAVARRETE, C. H. M.; RODRÍGUEZ, E. J. A. et al. Determinación de trihalometanos en aguas de consumo humano por microextracción en fase sólida-cromatografía de gases en Pereira, Colombia. Revista $\begin{array}{llllll}\text { Colombiana } & \text { Química, } & \text { v. } & 44, & \text { p. } & 23-29,\end{array}$ https://doi.org/10.15446/rev.colomb.quim.v44n1.54041

UN. Programa de las Naciones Unidas para el Desarrollo: Objetivos de Desarrollo Sostenibles, Colombia; herramientas de aproximación al contexto local. Bogotá: PNUD, 2015. p. 342.

UN. Programa de las Naciones Unidas para el Medio Ambiente: Evaluación de riesgos químicos. Ginebra: PNUMA/IPCS, 1999. p. 239.

WHO. Guidelines for drinking-water quality. 4th ed. Ginebra, 2017. p. 63.

ZARAGOZA-BASTIDA, A.; VALLADARES-CARRANZA, B.; ORTEGA-SANTANA, C.; ZAMORA-ESPINOSA, J.; VELÁZQUEZ-ORDOÑEZ, V.; APARICIO-BURGOS, J. Repercusiones del uso de los organoclorados sobre el ambiente y salud pública. Abanico Veterinario, v. 6, p. 43-55, 2016. 